\title{
A practical approach to the ground oscillation velocity measurement method
}

The Mining-Geology-Petroleum Engineering Bulletin UDC: $550.8: 552.1$

DOI: $10.17794 /$ rgn.2017.4.6

Original scientific paper

\author{
Siniša Stanković́; Mario Dobrilović; ;ječislav Bohanek \\ ${ }^{1}$ University of Zagreb, Faculty of Mining, Geology and Petroleum Engineering, Department of Mining Engineering and Geotechnics, \\ Pierottijeva 6, HR-10000 Zagreb, Croatia, Expert Associate \\ ${ }^{2}$ University of Zagreb, Faculty of Mining, Geology and Petroleum Engineering, Department of Mining Engineering and Geotechnics, \\ Pierottijeva 6, HR-10000 Zagreb, Croatia, Associate Professor \\ ${ }^{3}$ University of Zagreb, Faculty of Mining, Geology and Petroleum Engineering, Department of Mining Engineering and Geotechnics, \\ Pierottijeva 6, HR-10000 Zagreb, Croatia, Assistant Professor
}

\begin{abstract}
The use of an explosive's energy during blasting includes undesired effects on the environment. The seismic influence of a blast, as a major undesired effect, is determined by many national standards, recommendations and calculations where the main parameter is ground oscillation velocity at the field measurement location. There are a few approaches and methods for calculation of expected ground oscillation velocities according to charge weight per delay and the distance from the blast to the point of interest. Utilizations of these methods and formulas do not provide satisfactory results, thus the measured values on diverse distance from the blast field more or less differ from values given by previous calculations. Since blasting works are executed in diverse geological conditions, the aim of this research is the development of a practical and reliable approach which will give a different model for each construction site where blasting works have been or will be executed. The approach is based on a greater number of measuring points in line from the blast field at predetermined distances. This new approach has been compared with other generally used methods and formulas through the use of measurements taken during research along with measurements from several previously executed projects. The results confirmed that the suggested model gives more accurate values.
\end{abstract}

\section{Keywords}

Seismic influence of blasting, ground oscillation velocity, charge weight per delay.

\section{Introduction}

Blasting is an excavation technology, which is applied in most mining and civil engineering projects. Blasting as such, regarding mass application and its economical aspect, can be executed even in highly populated areas.

The basic demand is that with proper design, supervision and execution of blasting works, the undesired effects of blasting be nullified or reduced to an environmentally and technologically acceptable limit. By knowing the rock mass condition, status and type of potentially endangered structure and blasting parameters, blasting works can be executed in a safe manner without any damage to the surrounding structures. In literature and through experience, several approaches to define the criteria of possible damage to the structure in proximity to the blast have been defined:

(1) Experience-based equations to define the maximum charge weight per delay concerning reference to a

Corresponding author: Siniša Stanković

sinisa.stankovic@rgn.hr safe zone radius or a calculated value of ground oscillation velocities,

(2) Descriptive tables and scales for possible damage to the structures regarding the value of ground oscillation velocities,

(3) An approach based on the permitted value limits of ground oscillation velocities regarding different national and international norms, measured on a structure of interest.

In all the approaches, it is necessary to know the dependence of the ground oscillation velocity at a certain distance from the blast, and the rock mass in which the blasting is performed on the blasting parameters, often expressed as the maximum charge weight per delay. Due to the application of widely known forms and criteria, significant deviation had been noticed between calculated and measured values, thus the need arose for finding more accurate forms of dependence and estimation methods for ground oscillation velocity. Better knowledge of these dependencies and the possibility of calculating the expected ground oscillation velocity provide a framework for safer and more efficient execution of 
blasting works in urban areas. Approaches to determining criteria were established in parallel to the development of instruments for measuring certain parameters of seismic activity. In this case, the detonation of an explosive charge caused an artificial earthquake epicenter. The first approaches were descriptive to categorize the degree of damage elicited by the earthquake, and are derived from monitoring the impact of natural earthquakes with the latter joining the value of ground oscillation velocity as a measurable parameter. Examples of this approach include: S. V. Medvedev scale and the modified Mercalli scale (MMS). Since they are made on the basis of different physical phenomena, due to the duration, frequency and amplitude, in blasting they are applicable only conditionally. Another approach is represented by a number of empirical formulas proposed by various authors such as: Drukovani, Genschel, Nicholson, Johnson and Duval, Medvedev, Sadovski, Oriard, Hendron, Dowding and DuPond. Some forms include certain factors, which are influenced by the diversity of a rock mass, blasting parameters and potentially endangered facilities. The shortcoming in this approach is expressed through the fact that certain forms were created for specific situations of the blast field, the blasting environment and were based on different criteria of permitted ground oscillation velocity. Suggested patterns do not define the applicability to different distances from the blast field. In this review, we can generally set up two zones of interest from the standpoint of predicting the possibility of damage to the surrounding buildings: the close zone (up to several tens of meters) and distant zones (more than a few tens of meters). In the mentioned calculations, considering the distance of the observed structures and different criteria to define the possibility of damage, the results significantly vary in value of permitted mass charge weight per delay and safe distance from the object. The third approach of defining the possibility of damage to the structures surrounding the blast field is based on the various national and international standards. Within the requirements of standards, criteria of ground oscillation velocity had been accepted, but with substantially different permitted values, taking into account the frequency range of the measured oscillations. If the strictest criteria of norms, HRN DIN 41501:2011 (DIN 4150-1:2001), HRN DIN 4150-2:2011 (DIN 4150-2:1999) and HRN DIN 4150-3:2011 (DIN 4150-3:1999), would be accepted, the problem of predetermination of blasting parameters in order to achieve the values of ground oscillation velocity less than permitted at the point of interest. The proposed blasting parameters and the impact of such a blast field on the surrounding buildings are tested by measuring the ground oscillation velocity during the trial blasting at a safe distance from the protected structure. According to the measured values and applying the selected template, the designed values are corrected in order to maintain the value of the ground oscillation velocity below the per- missible limit. Such a process regularly depends on the experience of the designer and is subject to personal judgment, and in some cases, considering the limited space of the work site, there is no possibility to perform test blasting and measurements. On the other hand, the results of measurements carried out on wrongly defined distances from the blast are often unusable. Therefore, it is of most importance to use the precise form or model on the basis of the available input data, with the dependence of the ground oscillation velocity and blasting parameters, to calculate the expected value of the oscillation velocity of the observed object or on the measuring location. The most commonly used equation M. A. Sadovski (Krsnik, 1989) as well as other forms (Siskind, 2000, Dowding, 1985 and 1996), besides the theoretical analysis of the phenomenon, tentatively give a satisfactory basis for the preliminary analysis of expected ground oscillation velocity in general. Since most of the newer forms derived from statistical analysis of the measured values in various situations, they are conditionally applicable to certain specific cases. The main drawback of all these forms is the non-selective application of the input data. Other authors mainly provide calculations for the individual cases using existing forms (Anticevic et al, 2004, Ester et al, 2004, Vrkljan et al, 2004, Dobrilović et al, 2003).

\section{Field measurements and creation of a model}

The field measurements include testing of the macromodel conducted in the quarry rock mass. During research, the most influential parameters within the known characteristics to the environment in which blasting had been performed have been isolated. Those parameters are: ground oscillation velocity, charge weight per delay and the distance from the blast to the point of interest. The influence of geological diversity on the progress of the seismic waves, as well as human error is reduced to a minimum by using a large number of instruments placed along the measurement line during blasting. In order to ensure equal conditions, during conducted measurements the explosive used was of the same type and quantity and loaded in drilled holes of an identical diameter and depth. For the field research, a single hole was blasted at a time.

Field measurements consist of:

- Site selection,

- Preparation of boreholes,

- Selecting the type and quantity of explosives,

- Installation of measuring instruments at predetermined distances,

- Loading of explosive,

- Blasting and recording of ground oscillation velocity. 


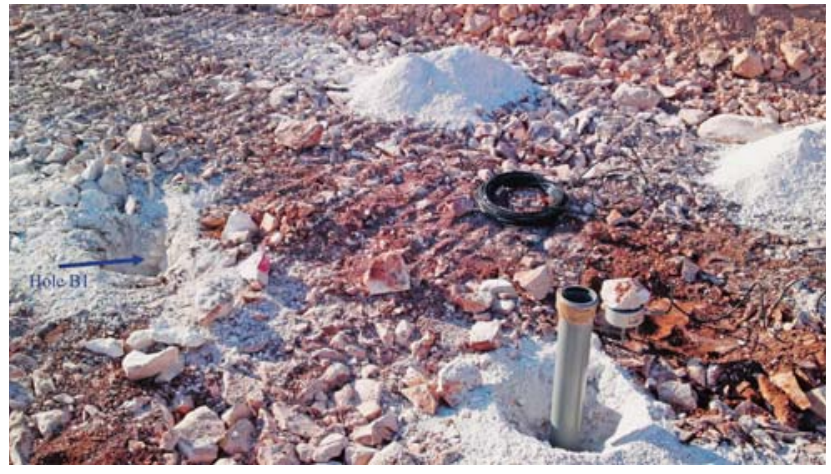

Figure 1: Surface and down the hole measurement points near hole $\mathrm{B} 1$

Locations for the field research were determined on the left (south) and right (north) edge of the quarry. A micro-location of each drilled hole was selected according to the available positions due to the regular quarry works. For drilling holes, a drill rig Tamrock Pantera was used. All holes were $89 \mathrm{~mm}$ in diameter and 3,0 m in depth. For the purposes of testing, instantaneous electrical detonators and two types of explosive were used: "Perunit 28E" and "ELEXIT", both $65 \mathrm{~mm}$ in diameter with similar characteristics.

Instruments used throughout research are Instantel BlastMate and Instantel Minimate. For each blast, 7-8 instruments were used, depending on the availability of the instruments. Measuring points were placed upon the surface and/or down the hole (see Figure 1), in a single line, crossing the center of the blast hole. The distances of the instruments from the blast hole were between 1,5 $\mathrm{m}$ and $80 \mathrm{~m}$.

An explosive was loaded at the bottom of the vertical hole. Stemming of the hole was done using drilled rock particles. Each loaded hole was blasted separately, and ground oscillation velocity was recorded. Instantaneous electrical detonators were fired with a manual dynamoelectrical machine.

\section{Data processing and analysis}

Obtained field measurement results are processed and analysed. Processing and data scrutiny include:
- Transfer and sorting of the measured data,

- Processing of data,

- Presentation of results.

Using the computer program "Blastware", data from the instruments was transferred into a computer and a report for each monitoring point was created separately. From the created reports or directly from the specified computer program, values of recorded ground oscillation velocity in relation to distance from the blast can be seen in Table 1. For the field research, measurements were done during 17 blasts, out of which one, Hole B1 (see Figure 2) will be described in detail in this paper.

Each model for the calculation of ground oscillation velocity in relation to the distance from the blast contains three major, interrelated variables, as follows:

$\mathrm{v}$ - ground oscillation velocity $(\mathrm{mm} / \mathrm{s})$,

$\mathrm{R}$ - distance from the blast ( $\mathrm{m})$,

$\mathrm{Q}$ - charge weight per delay $(\mathrm{kg})$.

The model is derived from measured data which was entered in the "scatter" chart.

While executing field measurements, the explosive mass was constant. To obtain a model depending on all

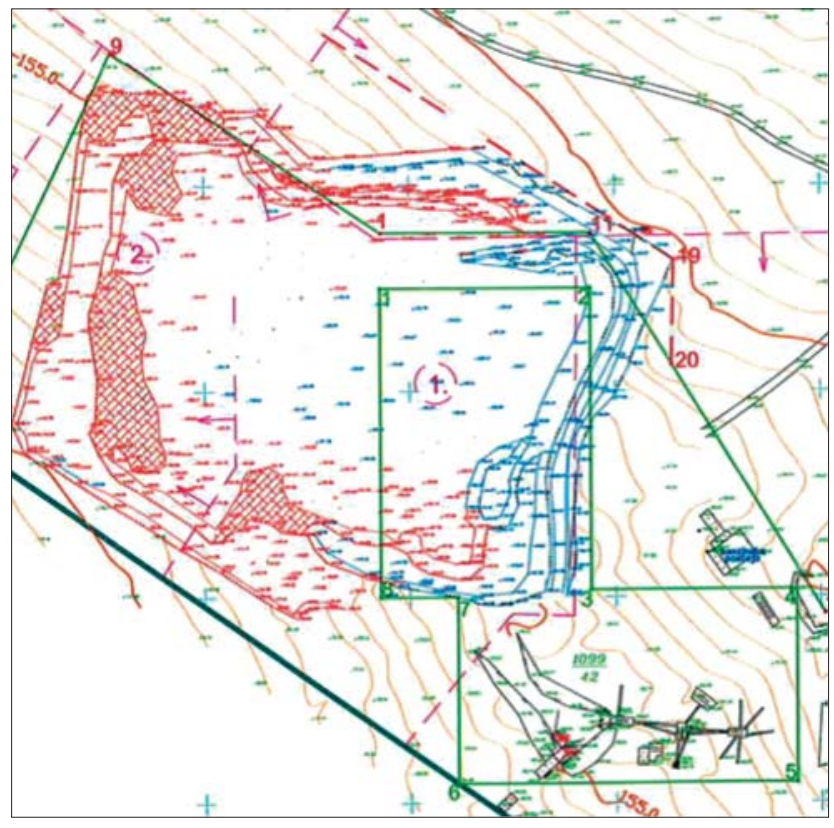

Figure 2: Position of Hole B1

Table 1: Measured components and resultant values of ground oscillation velocity in relation to distance from the blast

\begin{tabular}{|l|l|l|l|l|l|l|l|}
\hline Hole no. & $\begin{array}{l}\text { Measuring } \\
\text { point }\end{array}$ & Instrument & $\begin{array}{l}\text { Distance } \\
\text { from blast }(\mathrm{m})\end{array}$ & $\begin{array}{l}\mathrm{v}_{\mathrm{t}} \\
(\mathrm{mm} / \mathrm{s})\end{array}$ & $\begin{array}{l}\mathrm{v}_{\mathrm{v}} \\
(\mathrm{mm} / \mathrm{s})\end{array}$ & $\begin{array}{l}\mathrm{v}_{1} \\
(\mathrm{~mm} / \mathrm{s})\end{array}$ & $\begin{array}{l}\mathrm{V}_{\text {rez }} \\
(\mathrm{mm} / \mathrm{s})\end{array}$ \\
\hline \multirow{5}{*}{$\mathrm{MO}-1$} & BE 10234 & 5.00 & 39.20 & 173.00 & 161.00 & 207.00 \\
\cline { 2 - 8 } & MO-2 & 5938 & 10.00 & 11.70 & 55.90 & 47.80 & 64.50 \\
\cline { 2 - 9 } & MO-3 & BE 12944 & 15.00 & 16.50 & 23.00 & 26.20 & 29.80 \\
\cline { 2 - 9 } & MO-4 & 1280 & 25.00 & 15.10 & 26.50 & 20.10 & 34.60 \\
\cline { 2 - 9 } & MO-5 & BA 7958 & 30.00 & 12.30 & 9.27 & 6.60 & 15.80 \\
\cline { 2 - 9 } & MO-6 & BE $10774 / 1$ & 35.00 & 10.90 & 8.89 & 9.78 & 15.30 \\
\cline { 2 - 9 } & MO-7 & BE $10774 / 2$ & 40.00 & 4.19 & 7.11 & 6.48 & 8.05 \\
\hline
\end{tabular}


three main factors, the horizontal axis (x-axis) is associated with a reduced distance $\mathrm{Rsv}\left(\mathrm{m} / \mathrm{kg}^{1 / 3}\right)$, while the ordinate axis (y-axis) is associated with a ground oscillation velocity $\mathrm{v}(\mathrm{mm} / \mathrm{s})$.

Reduced distance is making the calculation of the ground oscillation velocity possible, for the case when both distance and charge weight per delay is variable. Reduced scaled distance is defined in Equation 1:

$$
R_{s v}=\frac{R}{\sqrt[3]{Q}}
$$

Where:

$R s v$ - reduced scaled distance $\left(\mathrm{m} / \mathrm{kg}^{1 / 3}\right)$,

$R$ - distance from the blast $(\mathrm{m})$,

$Q$ - charge weight per delay $(\mathrm{kg})$.

The form of the dependency model is a regression curve equation. It's a curve that best adapts to the original values in the "scatter" chart (Serdar, 1977). The chart for Hole B1 (see Figure 3) shows how a ground derives from a regression curve equation.

Additionally, the value of index of correlation R2, which is also shown on the chart, determines the strength of curvilinear reference (Serdar, 1977). The strength of curvilinear reference is presented as how well the measured data matches the regression curve. The index of correlation is nearer to number one if the measured data is closer to the regression curve, while a value is closer to zero if there is less overlapping, i.e. the original data is further away from the regression curve.

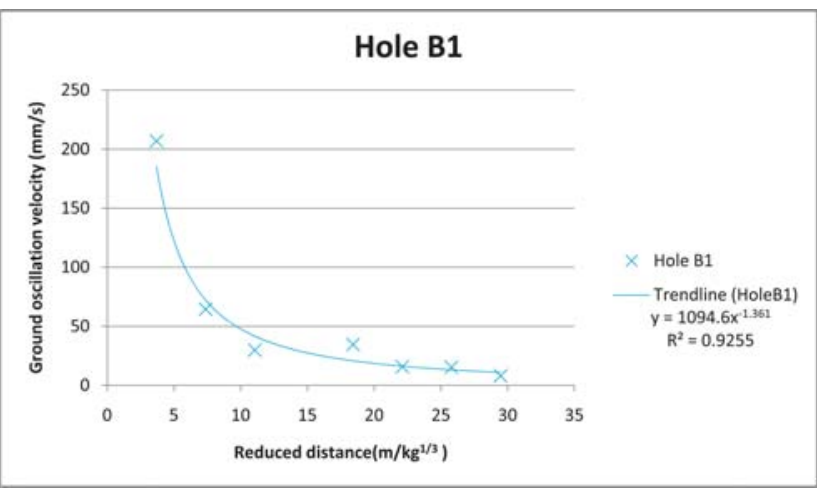

Figure 3: Ground oscillation velocity in relation to reduced distance for Hole $\mathrm{B}$

The regression curve for Hole B1 shown in Equation 2:

$$
v=1094,6 \cdot R_{s v}^{-1,361}
$$

Where:

$v-$ ground oscillation velocity $(\mathrm{mm} / \mathrm{s})$,

$R s v$ - reduced distance $(\mathrm{m} / \mathrm{kg} 1 / 3)$.

\section{Analysis (Discussion)}

After the field measurements and data processing, the obtained results accurately determine the dependence between ground oscillation velocity and reduced distance for the geological environment in which the measurements were made.

The results show that models obtained from regression curve equations vary. This phenomenon is due to the diversity of geological conditions on the surface of the quarry, positions of holes, different measurement directions and the imperfections of workers and instruments.

During the analysis, the proposed model was compared with commonly used models, the M. A. Sadovski (Krsnik, 1989) exact formula and the prediction models USBM and ISEE. The ground oscillation velocity as per M. A. Sadovski Equation 3:

$$
v=k\left(\frac{\sqrt[3]{Q}}{R}\right)^{n}
$$

Where:

$v$ - ground oscillation velocity $(\mathrm{cm} / \mathrm{s})$,

$Q$ - charge weight per delay $(\mathrm{kg})$,

$R$ - Distance from the blast (m),

$k$ - blasting coefficient,

$n$ - oscillation velocity reduction coefficient.

USBM prediction model is calculated by Equation 4:

$$
v=714\left(\frac{D}{W^{a}}\right)^{b}
$$

Where:

$v$ - ground oscillation velocity $(\mathrm{mm} / \mathrm{s})$,

$D$ - Distance from the blast (m),

$W$ - charge weight per delay $(\mathrm{kg})$,

$a$ - exponent (commonly about 0,5 ),

$b$-slope or decay exponent (commonly about -1,6). ISEE prediction model is calculated by Equation 5:

$$
v=1725\left(\frac{D}{\sqrt{W}}\right)^{-1,6}
$$

Where:

$v$ - ground oscillation velocity $(\mathrm{mm} / \mathrm{s})$,

$D$ - Distance from the blast (m),

$W$ - charge weight per delay $(\mathrm{kg})$,

To easily understand the results from the analysis, they are presented in graphical form. The horizontal axis ( $\mathrm{x}$-axis) is associated with a distance from the blast $\mathrm{R}$ (m), while the vertical axis (y-axis) is associated with ground oscillation velocity $\mathrm{v}(\mathrm{mm} / \mathrm{s})$. A comparison of the proposed model with models USBM, ISEE and M. A. Sadovski, was made based on a constant mass of explosive, hence, the ground oscillation velocity depends only on the distance from the blast.

The model proposed in this paper was compared with three possibilities of the Sadovski calculation model: two observation points closest to the blast (Sadovski-1), two observation points in medium distance from the 


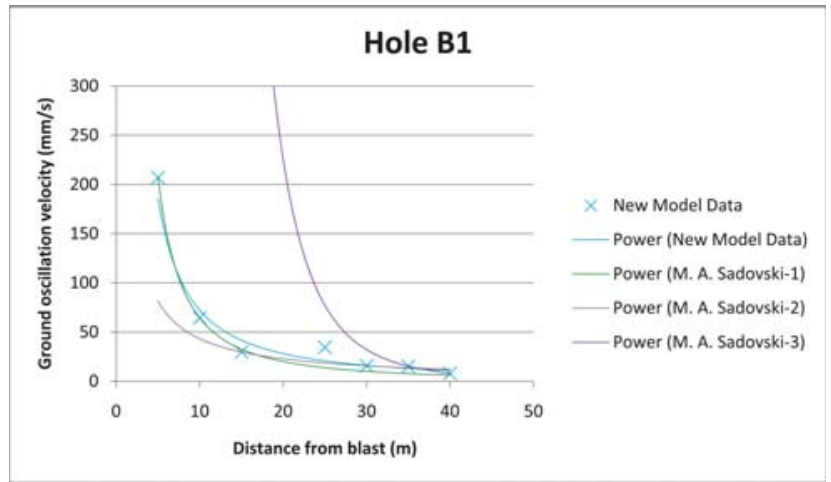

Figure 4: Comparison of the proposed model with M. A. Sadovski model for Hole B1

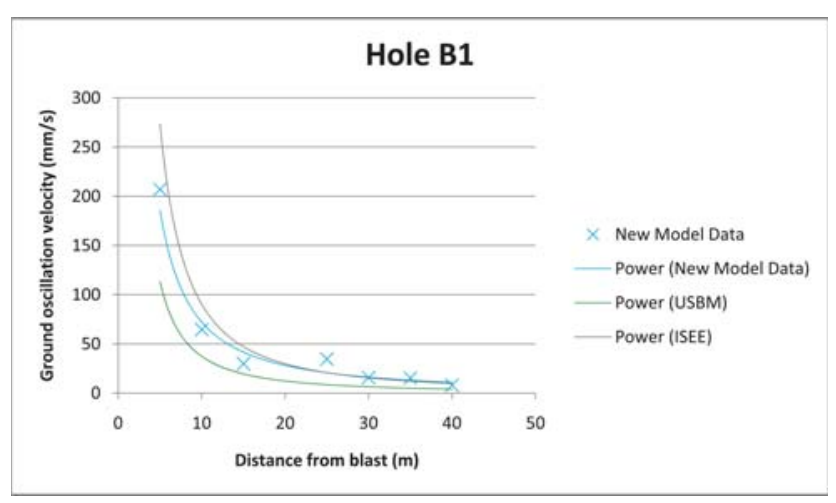

Figure 5: Comparison of the proposed model with USBM and ISEE models for Hole B1

blast (Sadovski-2) and two observation points furthest from the blast (Sadovski-3). The comparison of the proposed model with the USBM and ISEE models is shown in a separate chart, due to its different approach and for better clarification of the presented results.

Analysis shows the deviation of the calculated values from the measured values of ground oscillation velocity, for the new model, M. A. Sadovski formula and USBM and ISEE models. The first two charts present a comparison of the proposed model with M. A. Sadovski, USBM and ISEE models for the blast Hole B1 (see Figures 4 - 5). The second part of the analysis shows a comparison of the proposed model with M. A. Sadovski, USBM and ISEE models on measurements carried out in the framework of previously completed projects (see Figures 6 - 9).

On the basis of the presented results, it can be concluded that the application of the proposed model gives more reliable results than the M. A. Sadovski, USBM or ISEE methods. It has been confirmed that the M. A. Sadovski model can give a ground oscillation velocity value several times higher in the area closest to the blast. The comparison of the results from the proposed model and USBM and ISEE models shows that the ISEE model mostly gives higher values of ground oscillation velocity, while the USBM model values are mostly smaller than the measured values.

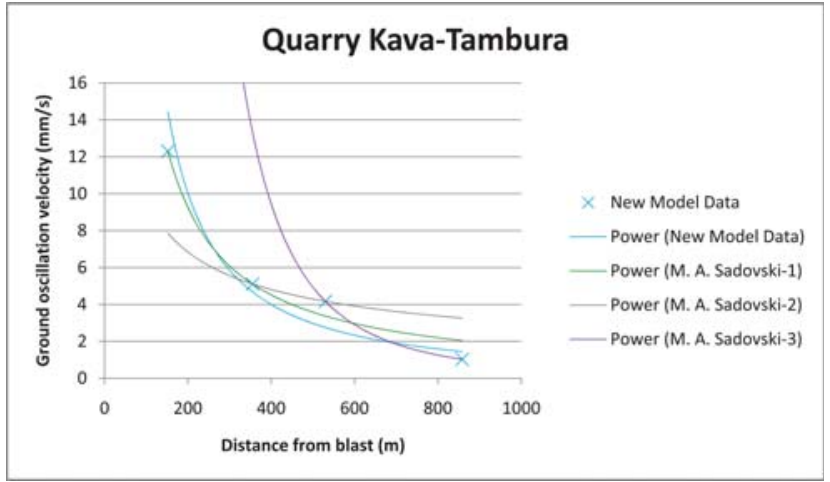

Figure 6: Comparison of the proposed model with M. A. Sadovski model for quarry Kava-Tambura

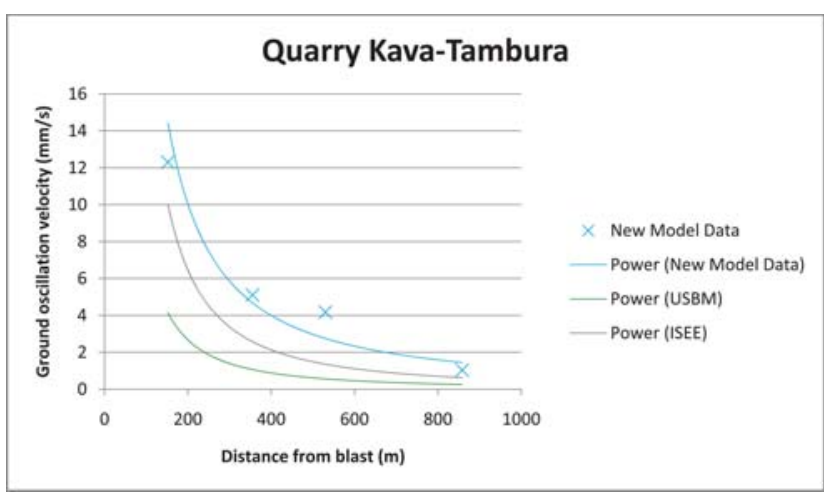

Figure 7: Comparison of the proposed model with USBM and ISEE models for quarry Kava-Tambura

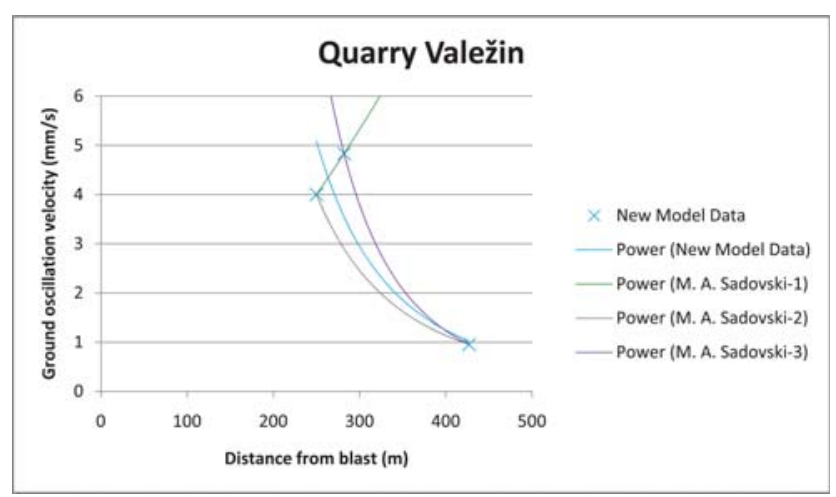

Figure 8: Comparison of the proposed model with M. A. Sadovski model for quarry Valežin

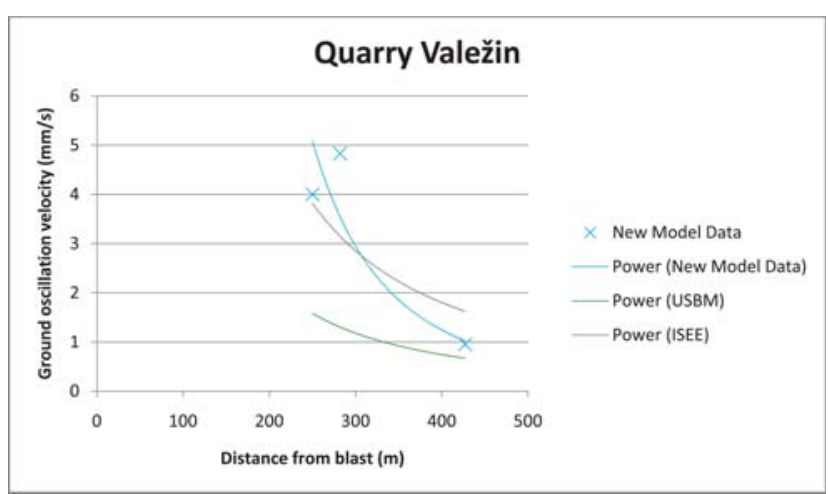

Figure 9: Comparison of the proposed model with USBM and ISEE models for quarry Valežin 


\section{Conclusions}

Based on extensive field measurements conducted in a quarry and consequential data processing, a new approach to measurement has been developed as well as a dependency model between ground oscillation velocity, charge weight per delay and the distance from the blast. The proposed approach is based on a larger number of instruments placed along a measurement line at predetermined distances from the blast, during the completion of a test blast. In this way, a more precise mathematical form which depends on the ground oscillation velocity in a specific rock mass is determined. The new model is set, from measured values of the ground oscillation velocity in combination with known blasting parameters, using the regression curve equation.

In the analysis, a comparison of the proposed model with frequently used models USBM, ISEE and M. A. Sadovski formula, was performed. It has been demonstrated that using the new approach and model gives more precise results than the values obtained using the M. A. Sadovski mathematical model, USBM or ISEE. The new approach and model are based on the following:

1. When performing a test blast at the new location, a larger number of instruments are placed in one or two measuring lines towards the object of interest (the protected structure).

2. Based on the measured values, a basic regression curve is set.

3. The application of the obtained results on further blasting works.

With a larger number of instruments, it is possible to reduce or even exclude the influence of geology, as well as instrument and human errors. Recommendation for further research is related to continuous measurements according to the new approach and model, creating a database containing all the available blasting parameters and geological conditions in blasting locations. Each control measurement during the blasting works complements the database as well as the model itself. Such a database could ultimately provide:

- More precise estimation of expected ground oscillation velocity,

- Optimal, predefined positions of measuring instruments,

- More accurate measured values,
- More reliable calculation results,

- Improved protection of surrounding structures from the unwanted effects of blasting,

- Safer blasting.

\section{References}

\section{Papers:}

Dobrilović, M., Ester, Z., Deković, Z. (2003): Measurement of seismic influences on tunnel support system caused by blasting with patronated explosives, Proceedings of 4th International Carpathian Control Conference ICCE 2003, 60-63, Podlubny, Igor; Kostur, Karol (eds.). High Tatras: TU Košice

Ester, Z., Vrkljan, D. (2004): Technology of excavation by blasting construction pit for university library in Split, Faculty of mining, geology and petroleum engineering, University of Zagreb, Zagreb

\section{Chapters in books or proceedings with editor(s):}

Antičević, H., Ester, Z., Dobrilović, M. (2004): Seizmički utjecaji miniranja na okolne objekte prilikom iskopa tunela „Brezik“, Proceedings of ECRBM '04 European conference of raw materials and coal: New Perspectives, / Muris Osmanagić (ed.). IP Svjetlost Sarajevo, Sarajevo

Vrkljan, D., Ester, Z., Dobrilović, M. (2004): Iskop tunela „Brinje“ miniranjem ispod objekata, Proceedings of ECRBM '04 European conference of raw materials and coal: New Perspectives, / Muris Osmanagić (ed.). IP Svjetlost Sarajevo, Sarajevo

\section{Books:}

Dowding, C. H. (1985): Blast vibration monitoring and control, Northwestern University, 297 p.

Dowding, C. H. (1996): Construction vibrations, vol. 1, Northwestern University, $284 \mathrm{p}$.

Dowding, C. H. (1996): Construction vibrations, vol. 2, Northwestern University, $610 \mathrm{p}$.

Siskind, D. (2000): Vibrations from blasting, International Society of Explosives Engineers, Clevland, 120 p.

\section{Books written in non-English language:}

Krsnik, J. (1989): Miniranje, Sveučilište u Zagrebu, Rudarskogeološko-naftni fakultet, $180 \mathrm{p}$.

Serdar, V. (1977): Udžbenik statistike, Školska knjiga, 401 p. 


\section{SAŽETAK}

\section{Novi pristup mjerenju brzine oscilacija tla}

Korištenje energije eksploziva tijekom miniranja uključuje neželjene učinke na okoliš. Seizmički utjecaj miniranja, kao jedan od glavnih neželjenih utjecaja, određuje se prema nekoliko standarda, preporuka i izračuna, gdje je glavni parametar brzina oscilacije tla na mjestu mjerenja. Postoji nekoliko pristupa i metoda za izračun očekivanih brzina oscilacija tla prema masi istodobno detoniranoga eksploziva i udaljenosti od eksplozije do točke interesa. Korištenje tih metoda i formula ne daje zadovoljavajuće rezultate, tako izmjerene vrijednosti na različitim udaljenostima od minskoga polja više se ili manje razlikuju od vrijednosti danih prethodnim proračunima. Budući da se minerski radovi izvode u različitim geološkim uvjetima, cilj je ovoga istraživanja razvoj novoga pristupa koji će dati drugačiji model za svako gradilište na kojemu je izvedeno ili će biti izvedeno miniranje. Pristup se temelji na većemu broju mjernih mjesta u liniji prema minskome polju na unaprijed određenim udaljenostima. Tijekom istraživanja, a poslije i na mjerenjima iz nekoliko već izvedenih projekata, novi pristup uspoređen je s drugim općenito korištenim metodama i formulama. Rezultati su potvrdili da predloženi model koji proizlazi iz novoga pristupa daje točnije vrijednosti.

\section{Ključne riječi:}

seizmički utjecaj miniranja, brzina oscilacija tla, masa istodobno detoniranog eksploziva

\section{Author(s) contribution}

Siniša Stanković - the main contribution is the developing the idea of new approach to measurement method, research collaboration and cooperation in approach development. Mario Dobrilović - the main contribution is research collaboration as well as cooperation in approach development. Vječislav Bohanek - the main contribution is cooperation in approach development. 